\title{
ANALISA LIMPASAN BERDASARKAN CURAH HUJAN MENGGUNAKAN MODEL ARTIFICAL NEURAL NETWORK (ANN) DI SUB DAS BRANTAS HULU
}

\author{
Ery Suhartanto $^{1}$, Evi Nur Cahya ${ }^{1}$, Lu'luil Maknun ${ }^{2}$ \\ ${ }^{1}$ Dosen Teknik Pengairan Fakultas Teknik Universitas Brawijaya \\ ${ }^{2}$ Mahasiswa Program Sarjana Teknik Jurusan Pengairan Universitas Brawijaya \\ Jalan MT. Haryono 167 Malang 65145 Indonesia
}

\begin{abstract}
ABSTRAK: Data debit biasanya tersedia lebih sedikit dibandingkan data curah hujan, sehingga perlu dicari suatu hubungan antara aliran sungai yang diterapkan dalam periode tersedia data curah hujan di suatu wilayah DAS. Tujuan dari studi ini adalah untuk mengetahui kesesuaian metode berdasarkan analisis validasi data antara debit pengamatan dengan debit model. Metode yang dilakukan dengan pemodelan debit berdasarkan curah hujan dengan model Artificial Neural Network (ANN) program MATLAB R2014b. Sub DAS Brantas Hulu digunakan sebagai studi kasus karena sering mengalami permasalahan limpasan. Validasi dari metode ANN diuji dengan Root Mean Square Error (RMSE), Nash-Sutcliffe Efficiency (NSE), Koefisien Korelasi (R) dan Kesalahan Relatif (KR). Dari hasil kalibrasi menggunakan Model ANN diperoleh data yang paling baik terdapat pada data lima tahun epoch 500. Hasil verifikasi berdasarkan nilai $\mathrm{R}$ mempunyai hubungan yang relatif baik antara debit pengamatan dengan debit model. Hasil validasi menunjukkan kevalidan pada data satu tahun epoch 500 .
\end{abstract}

Kata kunci: limpasan, model artifical neural network (ANN), uji nash sutchlife efficient (NSE), koefisien korelasi (R).

\begin{abstract}
Discharge data is usually less available than rainfall data, so it is necessary to find a relationship between river flows that are applied in the period available rainfall data in $a$ watershed area. The purpose of this study is to determine the suitability of the method based on the analysis of data validation between the observed discharge and the model discharge. The method is done by modeling the discharge based on rainfall with the Artificial Neural Network (ANN) MATLAB R2014b program. The Upper Brantas Watershed is used as a case study because it often has runoff problems. Validation of the ANN method was tested with Root Mean Square Error (RMSE), Nash-Sutcliffe Efficiency (NSE), Correlation Coefficient (R) and Relative Error (KR). From the results of calibration using the ANN Model, the best data is found in the five years data of epoch 500. Verification results based on the value of $R$ have a relatively good relationship between observation discharges with model discharges. The validation results show the validity in a year data of epoch 500.
\end{abstract}

Keywords: discharge, artifical neural network (ANN), nash sutchlife efficient test (NSE), correlation coefficient $(R)$.

Daerah Aliran Sungai terbagi menjadi tiga bagian daerah yaitu hulu, tengah dan hilir. Perencanaan DAS hulu seringkali menjadi titik fokus mengingat bahwa dalam suatu DAS, daerah hulu dan hilir mempunyai keterkaitan biogeofisik melalui daur hidrologi. Aktivitas alih fungsi lahan yang dilaksanakan di daerah hulu dapat memberikan dampak di daerah hilir 
dalam bentuk perubahan fluktuasi debit air dan transpor sedimen serta material terlarut lainnya. Salah satu wilayah DAS yang rentan akan alih fungsi lahan adalah Sub DAS Brantas Hulu.

DAS Brantas Hulu mengalami permasalahan tentang peralihan tata guna lahan yang menyebabkan kemampuan infiltrasinya menjadi berkurang (Nurrisqi, 2012). Akibatnya, air hujan yang jatuh pada daerah aliran sungai (DAS) akan menjadi limpasan permukaan (surface runoff). Oleh karena itu, terjadi peningkatan aliran permukaan yang berpengaruh terhadap aliran debit pada outlet DAS dan menyebabkan banjir. Oleh karena itu, dibutuhkan analisa hidrologi menggunakan model berbasis teknologi dengan harapan dapat memprediksikan kejadian limpasan yang akan terjadi. Dikarenakan data debit ALWR biasanya tersedia lebih sedikit dibandingkan data curah hujan, maka dapat dicari suatu hubungan antara aliran sungai yang diterapkan dalam periode tersedia data curah hujan khususnya di suatu wilayah DAS. Automatic Water Level Recorder (AWLR) merupakan alat untuk mengukur tinggi muka air pada sungai, danau, ataupun aliran irigasi.

Dari studi ini dilakukan untuk memprediksikan limpasan yang terjadi dengan mengkaji antara keterkaitan curah hujan menggunakan model Artifical Neural Network (ANN) software MATLAB R2014b yang diharapkan akan memperoleh nilai yang mendekati debit stasiun AWLR pengamatan. Beberapa penelitian mengenai limpasan berdasarkan curah hujan menggunakan berbagai metode antara lain Aplikasi Jaringan Syaraf Tiruan (JST) untuk Analisis Debit DAS Bedadung di Kabupaten Jember (Suhardi, et al, 2017). Analisa Hujan-Limpasan Menggunakan Model Artifical Neural Network di Sub DAS Lesti (Siska W, et al, 2016). Aplikasi Metode MOCK, NRECA, Artifical Neural Network, dan Regresi dalam Pengalihragaman HujanLimpasan dengan Pembangkitan Data Debit AWLR Matua (Rahimatus Sakinah, et al, 2015). Perbandingan Model Curah Hujan Limpasan Metode Jaringan Syaraf Tiruan dengan Metode Sacramento (Denny Y, et al, 2014). Artifical Neural Network untuk
Pemodelan Curah Hujan-Limpasan pada Daerah Aliran Sungai (DAS) di Pulau Bali (Sila Dharma, et al, 2011).

\section{BAHAN DAN METODE Lokasi Studi}

Lokasi studi merupakan Bagian hulu dari Sub DAS Brantas. Secara administratif, Sub DAS Brantas Hulu terletak di Provinsi Jawa Timur yang meliputi Kota Batu, Kota Malang, dan Kabupaten Malang. Secara astronomis, Sub DAS Brantas Hulu terletak pada posisi $7^{0} 45^{\prime} 36^{\prime \prime}$ LS sampai $8^{0} 03^{\prime} 00^{\prime \prime}$ LS dan $112^{0} 34^{\prime} 12^{\prime \prime}$ BT sampai $112^{0} 25^{\prime} 48^{\prime \prime}$ BT dengan luasan sekitar $789,184 \mathrm{~km}^{2}$. Secara geografis meliputi 30 kecamatan di Kabupaten Malang dan 3 Kecamatan di Kotamadya Malang. Dalam studi ini digunakan 20 pos stasiun hujan yang berada di Sub DAS Brantas Hulu dengan luas 789, $184 \mathrm{~km}^{2}$. Peta lokasi studi dapat dilihat pada Gambar 1 .

\section{Data}

Data yang digunakan dalam studi ini antara lain adalah:

1. Data curah hujan dari 20 pos stasiun hujan selama 10 tahun (2008-2017).

2. Data debit AWLR Gadang selama 10 tahun (2008-2017).

\section{Metode Analisis}

Dalam studi ini dilakukan analisa validasi data antara perbandingan data debit AWLR (Automatic Water Level Recorder) pengamatan dengan data debit Model ANN. Sebelum dilakukan validasi, data yang diperoleh dilakukan uji kualitas data yang meliputi data hujan dengan normal ratio, uji konsistensi data, uji ketiadaan trend, uji stasioner dan pembangkitan data debit metode regresi.

\section{Estimasi Data Hujan Menggunakan Normal Ratio Method}

Data yang hilang atau kesenjangan data suatu pos penakar hujan pada saat tertentu, dapat diisikan dengan bantuan data yang tersedia dari pos-pos penakar hujan disekitarnya pada waktu yang sama (Soemarto, 1999). 


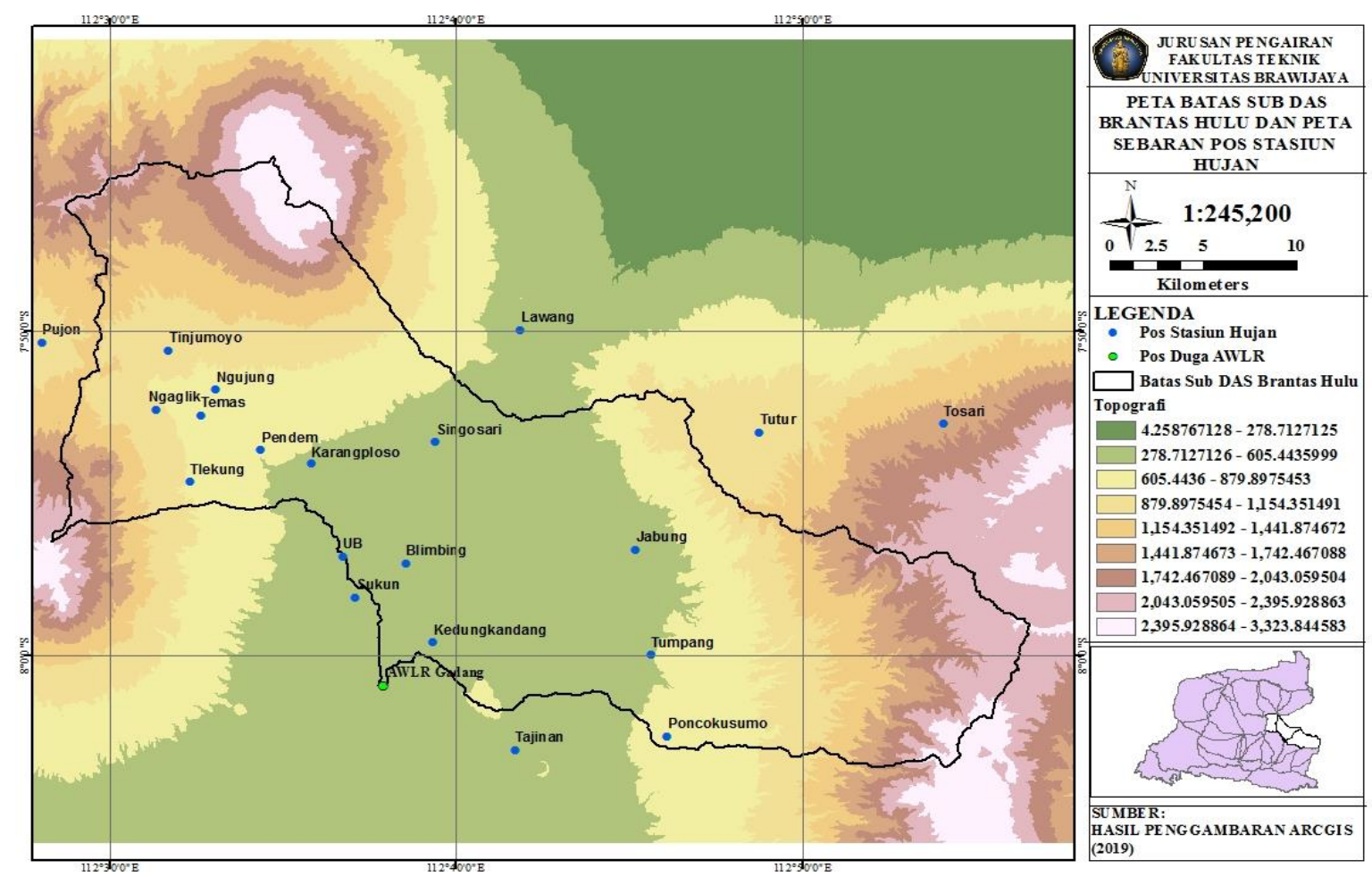

Gambar 1 Peta Sub DAS Brantas Hulu

\section{Uji Konsistensi}

Uji konsistensi adalah suatu uji kebenaran data lapangan yang tidak dipengaruhi oleh kesalahan saat pengukuran dan digambarkan dengan keadaan sebenarnya. Dalam uji konsistensi data hidrologi, umumnya digunakan beberapa metode seperti Metode Kurva Massa Ganda dan Metode RAPS (Rescaled Adjusted Partial Sums) (Harto, 1990).

\section{Uji Ketiadaan Trend}

Uji ini dilakukan untuk mengetahui ada tidak adanya trend atau variasi dalam data. Trend dapat dijelaskan sebagai korelasi antara waktu dengan varian dari suatu variabel hidrologi. Jika terdapat trend maka data tidak disarankan dalam analisa. Data yang digunakan pada uji ini harus menghasilkan data yang homogen, artinya data yang berasal dari populasi yang jenisnya sama. Dalam uji ini dilakukan Uji peringkat Korelasi Spearman, Uji Mann-Whitney dan Uji Cox-Stuart (Soewarno, 1995).

\section{Uji Stasioner}

Uji stasioner digunakan untuk menguji kestabilan varian dan kestabilan nilai ratarata dari sebuah deret berkala seperti data curah hujan. Hasil yang diharapkan dari uji ini adalah data yang bersifat homogen, yakni hasil kedua uji menunjukkan data yang stabil. Uji ini dilakukan dengan Uji $\mathrm{F}$ dan Uji $\mathrm{T}$ (Soewarno, 1995).

\section{Curah Hujan Rerata Daerah Polygon Thiessen}

Curah hujan rerata daerah ini digunakan untuk memperoleh satu nilai besaran hujan yang dapat mewakili keseluruhan nilai dalam DAS (Triatmodjo, 2006). Pada studi ini terdapat 20 pos stasiun hujan yang berada disekitar Sub DAS Brantas Hulu, sehingga diperlukannya nilai curah hujan rerata daerah. Adapun curah hujan rerata daerah pada studi ini dihitung menggunakan metode Polygon Thiessen dengan alat bantu Software ArcGis 10.2, dengan anggapan sesuai dengan karakteristik Sub DAS Brantas Hulu yang penyebarannya stasiun hujannya ditinjau tidak merata.

\section{Pembangkitan Data Debit Metode Regresi}

Model regresi ini merupakan salah satu model statistik yang dapat digunakan untuk mengetahui apakah ada hubungan antara dua variabel atau lebih. Hubungan antara dua atau lebih dalam variabel hidrologi dapat dinyatakan dalam rumus matematik sehingga merupakan suatu model, yang dapat 
digunakan untuk berbagai keperluan analisis hidrologi, yaitu peramalan (prediction), perpanjangan (extension), memperbaiki atau mengecek ketelitian data, dan pengisian data pada periode kosong (Soewarno, 1995).

\section{Artificial Neural Network (Jaringan Syaraf Tiruan)}

Jaringan Saraf Tiruan adalah sistem pemroses informasi yang memiliki karakteristik mirip dengan jaringan syaraf biologi (Siang, 2005). Sehingga disimpulkan Jaringan Syaraf Tiruan atau dengan kata lain Artificial Neural Network merupakan sistem pengolahan informasi yang terinspirasi dari jaringan saraf secara biologis, seperti proses informasi pada otak manusia. Terdapat beberapa kelebihan dan kekurangan dari JST yang diharapkan mampu menganalisa data debit yang bisa mendekati kondisi data dilapangan.

Dalam studi ini digunakan model Artifical Neural Network (ANN) dengan metode backpropagation. Backpropagation adalah algoritma pembelajaran yang terawasi dan biasanya digunakan oleh percepton dengan banyak lapisan untuk mengubah bobot-bobot yang terhubung dengan neuronneuron yang ada pada lapisan tersembunyinya (Kusumadewi, 2003).

\section{MATLAB (Matrix Laboratory)}

MATLAB atau singkatan Matrix Laboratory adalah sebuah perangkat lunak yang digunakan untuk pemograman dengan berisikan fungsi toolbox yang dapat memudahkan perhitungan. MATLAB merupakan perangkat lunak yang cocok digunakan untuk menyelesaikan model jaringan syaraf tiruan. Pengguna tinggal memasukkan vektor masukan, target, model dan parameter yang ingin dicapai (laju pemahaman, threshold, bias, dll). Dalam studi digunakan software MATLAB dengan seri R2014b.

\section{Transformasi Data}

Sebelum menggunakan data dengan metode atau teknik yang akan diterapkan, kita harus melakukan praprosesing terhadap data. Hal ini dilakukan untuk mendapatkan hasil analisis yang lebih akurat dalam pemakaian teknik machine learning atau data mining. Dalam beberapa hal, praprosesing dapat membuat nilai data menjadi lebih kecil tanpa merubah informasi yang dikandungnya. Dalam studi ini digunakan normalisasi dengan fungsi sigmoid biner (0$1)$.

$X^{\prime}=\frac{X-X \min }{X \max -X \min } x(B A-B B)+B B$

Dengan

$\mathrm{Xmax}=$ nilai maksimum pada data

$\mathrm{Xmin}=$ nilai minimum pada data

\section{Uji Validasi}

Validasi (validation) merupakan proses evaluasi terhadap model untuk mendapatkan gambaran tentang tingkat ketidakpastian yang dimiliki oleh suatu model dalam memprediksi proses hidrologi. Umumnya validasi dilakukan dengan menggunakan data diluar periode data yang digunakan untuk kalibrasi (Indarto, 2012).

Untuk melakukan uji validasi dilakukan dengan beberapa pengujian, antara lain:

(1) Root Mean Squared Error (RMSE)

$$
\begin{aligned}
& R M S E=\sqrt{\frac{\sum_{i=1}^{n}(X-Y)^{2}}{n}} \\
& \text { RMSE =nilai Root Mean Square Error } \\
& \mathrm{Y} \quad=\text { nilai permodelan (predicted value) } \\
& \left(\mathrm{m}^{3} / \mathrm{dt}\right) \\
& \mathrm{X}=\text { nilai pengamatan (observed value) } \\
& \left(\mathrm{m}^{3} / \mathrm{dt}\right) \\
& n \quad=\text { jumlah data }
\end{aligned}
$$

(2) Uji Kesalahan Relatif

$$
K R=\frac{\sum_{i=1}^{n}(X-Y)}{\sum X} x 100
$$

Keterangan:

$$
\begin{aligned}
\mathrm{Kr} & =\text { kesalahan relatif }(\%) \\
\mathrm{X} & =\text { nilai pengamatan }\left(\mathrm{m}^{3} / \mathrm{dt}\right) \\
\mathrm{Y} & =\text { nilai hasil pemodelan }\left(\mathrm{m}^{3} / \mathrm{dt}\right)
\end{aligned}
$$

(3) Koefisien Korelasi

Uji ini bertujuan untuk melihat hubungan antar kedua variabel (hasil pengamatan dan hasil perhitungan) berdasarkan kriteria yang disajikan pada Tabel 1.

$$
R=\frac{n \sum_{i=1}^{n} X Y-\sum_{i=1}^{n} X \sum_{i=1}^{n} Y}{\sqrt{n \sum_{i=1}^{n} X^{2}-\left(\sum_{i=1}^{n} X\right)^{2}} \sqrt{n \sum_{i=1}^{n} Y^{2}-\left(\sum_{i=1}^{n} Y\right)^{2}}}
$$

Keterangan:

$\mathrm{R}=$ nilai korelasi antara variabel $x$ dan $y$ $\mathrm{X}=$ nilai pengamatan atau observasi $\left(\mathrm{m}^{3} / \mathrm{dt}\right)$ $\mathrm{Y}=$ nilai permodelan $\left(\mathrm{m}^{3} / \mathrm{dt}\right)$

$n$ = jumlah data 
Tabel 1 Kriteria Nilai Koefisien Korelasi

\begin{tabular}{ll}
\hline Nilai R & Interpretasi \\
\hline $0-0,19$ & Sangat Rendah \\
$0,20-0,39$ & Rendah \\
$0,40-0,59$ & Sedang \\
$0,60-0,79$ & Kuat \\
$0,8-1$ & Sangat Kuat \\
\hline
\end{tabular}

Sumber: Sugiyono (2017)

(4) Nash-Sutcliffe Efficiency (NSE)

Uji efisiensi Nash-Sutcliffe bertujuan untuk mengevaluasi kesahihan pada model dengan menggunakan kriteria yang disajikan pada Tabel 2.

$$
N S E=1-\frac{\sum_{i=1}^{n}(X-Y)^{2}}{\sum_{i=1}^{n}(X-\bar{X})^{2}}
$$

Keterangan:

NSE $=$ koefisien Nash-Sutcliffe

$n \quad=$ jumlah data

$\mathrm{Y}=$ nilai dari hasil permodelan $\left(\mathrm{m}^{3} / \mathrm{dt}\right)$

$\mathrm{X}=$ nilai dari hasil pengamatan $\left(\mathrm{m}^{3} / \mathrm{dt}\right)$

$\bar{X}=$ rerata nilai hasil pengamatan $\left(\mathrm{m}^{3} / \mathrm{dt}\right)$

Tabel 2 Kriteria Nilai Nash Sutcliffe Efficiency (NSE)

\begin{tabular}{ll}
\hline Nilai NSE & Interpretasi \\
\hline NSE $>0,75$ & Baik \\
$0,36<$ NSE $<0,75$ & Memenuhi \\
NSE $<0,36$ & Tidak Memenuhi \\
\hline
\end{tabular}

Sumber: Motovilov.et al.1999

\section{HASIL DAN PEMBAHASAN}

Data yang digunakan untuk analisis adalah data dengan periode bulanan. Sebelum dilakukan analisis validasi, data curah hujan dan debit dilakukan uji Konsistensi, uji Ketiadaan Trend dan uji Stasioner. Dari hasil uji konsistensi didapatkan bahwa data-data tersebut konsisten, uji Ketiadaan Trend dilakukan dengan Uji Spearman, Uji MannWhitney dan Uji Cox-Stuart dan pada Uji Stasioner digunakan Uji F dan Uji T. Hasil yang didapakan berdasarkan uji tersebut adalah stabil dan tidak menunjukkan adanya trend, sehingga dapat disimpulkan bahwa data-data tersebut adalah homogen maka data tersebut dapat digunakan untuk analisis selanjutnya.

Data pos stasiun hujan perlu ditransformasikan menjadi hujan wilayah, dalam studi ini digunakan metode polygon thiessen untuk mendapatkan hujan wilayah yang hasilnya disajikan pada Gambar 2 dan Tabel 3.

Berdasarkan Gambar 2 menghasilkan garis-garis sumbu pada garis penghubung antara 20 pos hujan yang berdekatan. Cara ini diperoleh dengan membuat polygon yang memotong tegak lurus pada tengah-tengah garis penghubung 20 pos stasiun hujan. Sehingga dihasilkan tiap pos hujan mewakili luasan yang dibentuk oleh polygon yang disajikan pada Tabel 3 .

Tabel 3 Nilai Faktor Pengaruh Luas Pos Hujan (Kr)

\begin{tabular}{ccrl}
\hline No & Stasiun Hujan & $\begin{array}{c}\text { Luas } \\
\text { Daerah } \\
\left(\mathbf{k m}^{2}\right)\end{array}$ & KR \\
\hline 1 & Kedungkandang & 37,487 & 0,048 \\
2 & Lawang & 9,955 & 0,013 \\
3 & Tinjumoyo & 98,323 & 0,125 \\
4 & UB & 9,173 & 0,012 \\
5 & Sukun & 3,765 & 0,005 \\
6 & Tajinan & 8,703 & 0,011 \\
7 & Tumpang & 83,910 & 0,106 \\
8 & Jabung & 94,245 & 0,119 \\
9 & Blimbing & 35,378 & 0,045 \\
10 & Tutur & 34,048 & 0,043 \\
11 & Singosari & 73,413 & 0,093 \\
12 & Tlekung & 26,696 & 0,034 \\
13 & Pujon & 10,150 & 0,013 \\
14 & Karangploso & 34,561 & 0,044 \\
15 & Pendem & 18,265 & 0,023 \\
16 & Temas & 7,737 & 0,010 \\
17 & Ngujung & 49,241 & 0,062 \\
18 & Ngalik & 28,133 & 0,036 \\
19 & Poncokusumo & 75,639 & 0,096 \\
20 & Tosari & 50,361 & 0,064 \\
\hline & TOTAL & 789,184 & 1 \\
\hline & & &
\end{tabular}

\section{Perhitungan Koefisien Aliran}

Koefisien aliran adalah bilangan yang menunjukkan perbandingan antara besarnya air larian terhadap besarnya curah hujan. Angka $\mathrm{C}$ berkisar antara 0 hingga 1. Angka 0 menunjukkan bahwa semua air hujan terdistribusi menjadi air intersepsi dan terutama infiltrasi. Sedang angka $\mathrm{C}=1$ menunjukkan bahwa semua air hujan mengalir sebagai air larian. Di lapangan, 
angka koefisien air larian biasanya lebih besar dari 0 dan lebih kecil dari 1 .

\section{Perhitungan Debit AWLR Metode ANN}

Perhitungan debit AWLR dengan metode Artificial Neural Network (ANN) dibantu dengan software MATLAB R2014b.
Dalam pengolahan data input menggunakan data curah hujan, koefisien aliran dan ditambahkan dengan data jumlah hari hujan serta data debit yang dijadikan sebagai data target. Untuk data yang digunakan dalam perhitungan ANN selama 10 tahun dengan pembagian 2 kelompok data misal 5-5 tahun.

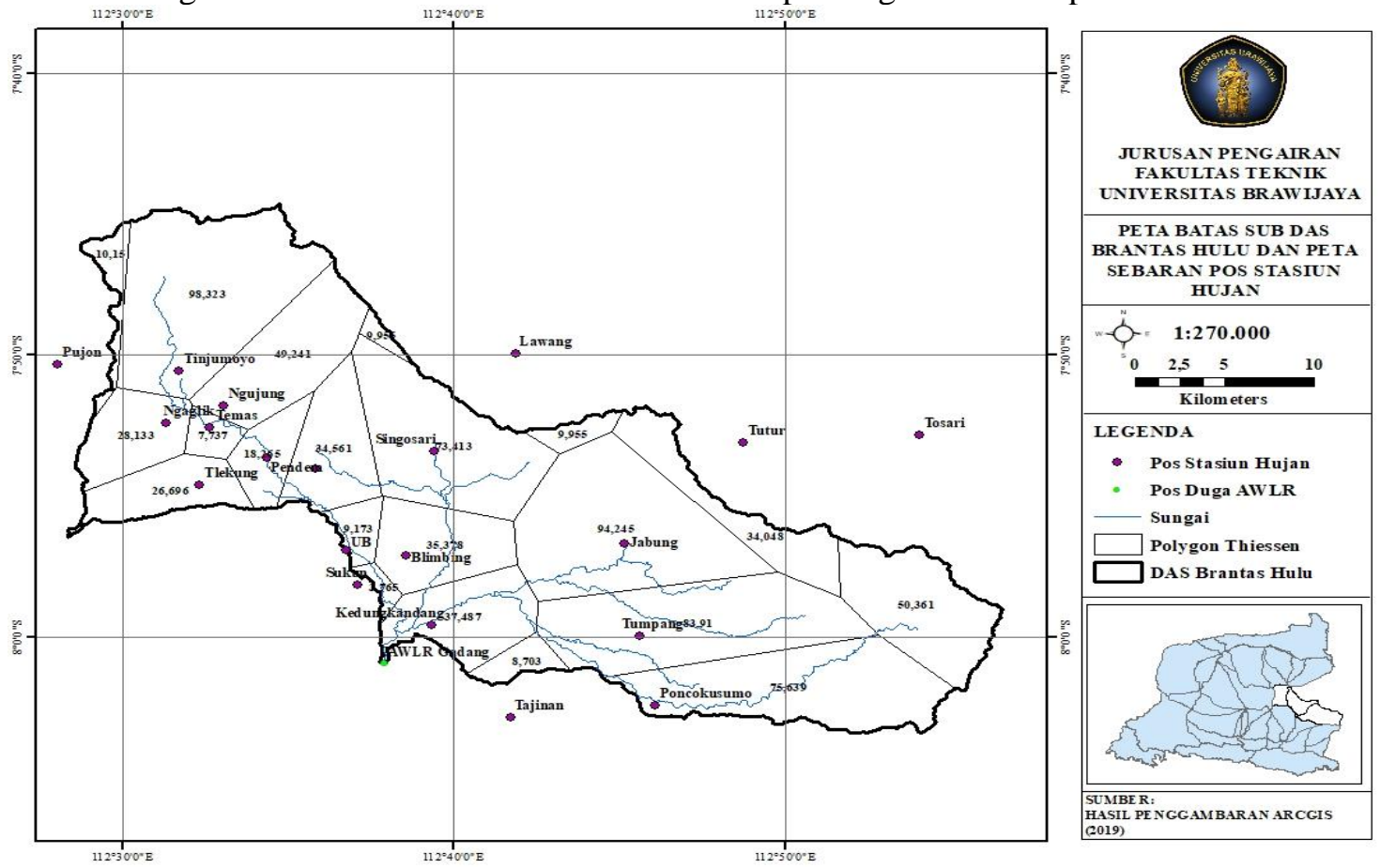

Gambar 2 Peta Luas Pengaruh Stasiun Hujan dengan Metode Polygon Thiessen

Maksudnya, data 5 tahun digunakan sebagai training (pelatihan) atau kalibrasi model dengan data debit AWLR target lapangan, sedangkan 5 tahun digunakan sebagai Validasi atau testing (pengujian). Dalam studi digunakan percobaan menggunakan epoch 500, 1000, 1500 dan 2000. Epoch merupakan perulangan atau iterasi dari proses yang dilakukan untuk mencapai target yang telah ditentukan.

Misalnya, pada hasil Training dari software MATLAB menghasilkan nilai pada training pertama dan training optimum dengan epoch 500 yang disajikan pada Gambar 3 dan Gambar 4. Gambar a merupakan hasil plotting mean square error (MSE) dengan menunjukkan perform train, validation dan test. Gambar 3a menghasilkan perform validasi terbaik pada epoch 5 dengan nilai $10^{-1}$ sedangkan pada Gambar 4a menunjukkan perform validasi terbaik pada epoch 0 dengan nilai $10^{-2}$. Dimana hal tersebut dapat dilihat bahwa semakin kecil nilai MSE yang dihasilkan, maka jaringan itu dikatakan berhasil dan mendekati target.
Gambar b merupakan status pelatihan network yang menjelaskan bagaimana nilai gradien, momentum dan grafik pengecekan validasi pada pelatihan ANN. Pada Gambar $3 \mathrm{~b}$ dihasilkan gradien sebesar $10^{-6}$, momentum sebesar $10^{-5}$ dan pengecekan validasi yang dilakukan hanya sampai pada epoch 495. Sedangkan pada 4b menunjukkan nilai gradien $10^{-7}$, momentum sebesar $10^{-6}$ dan pengecekan validasi sesuai epoch sebesar 500. Hal tersebut mempengaruhi jika nilai gradien semakin kecil maka pemodelan telah mendekati konstan dan cocok dengan pelatihan jaringan. Semakin kecil nilai momentum yang dihasilkan maka jaringan dapat dikatakan berhasil. Sedangkan untuk pengecekan validasi sesuai epoch menyebabkan jaringan semakin pintar dan output yang dihasilkan akan mendekati target yang kita inginkan.

Gambar c merupakan grafik hubungan antara hasil output pda tahap pelatihan dengan target yang ditentukan. Grafik ini menunjukkan nilai regresi untuk training, validation, test dan all yang mendekati 1 
dengan hasil output dari pemodelan telah mendekati target yang ingin dicapai. Pada Gambar 3c menunjukkan nilai regresi yang masih jauh dari ketentuan sehingga dilakukan training optimum seperti yang disajikan pada Gambar 4c dengan hasil regresi mendekati 1.

\section{Analisis Validasi Data}

Dalam studi ini, proses validasi digunakan untuk memberi gambaran perbandingan antara data debit AWLR lapangan dengan data debit AWLR model ANN. Sebelum masuk tahap validasi data, terlebih dahulu dilakukan kalibrasi dan verifikasi data. Kalibrasi merupakan proses optimalisasi nilai parameter untuk meningkatkan koherensi antara respon hidrologi untuk debit pengamatan dan debit AWLR Model. Tahap kalibrasi dilakukan dengan rentang data 5 tahun, 6 tahun, 7 tahun, 8 tahun dan 9 tahun. Sedangkan verifikasi merupakan suatu proses setelah tahap kalibrasi selesai dilakukan yang berfungsi untuk menguji kinerja model pada data di luar periode kalibrasi dengan rentang data sisanya yaitu 5 tahun, 4 tahun, 3 tahun, 2 tahun dan 1 tahun. Uji ini menggunakan Root Mean Square Error (RMSE), Kesalahan Relatif (KR), Koefisien Korelasi (R) dan Nash Sutchlife Efficient (NSE). Untuk hasil rekapitulasi kesesuaian metode dari tahap kalibrasi, verifikasi dan validasi disajikan pada Tabel 4 dan 5.

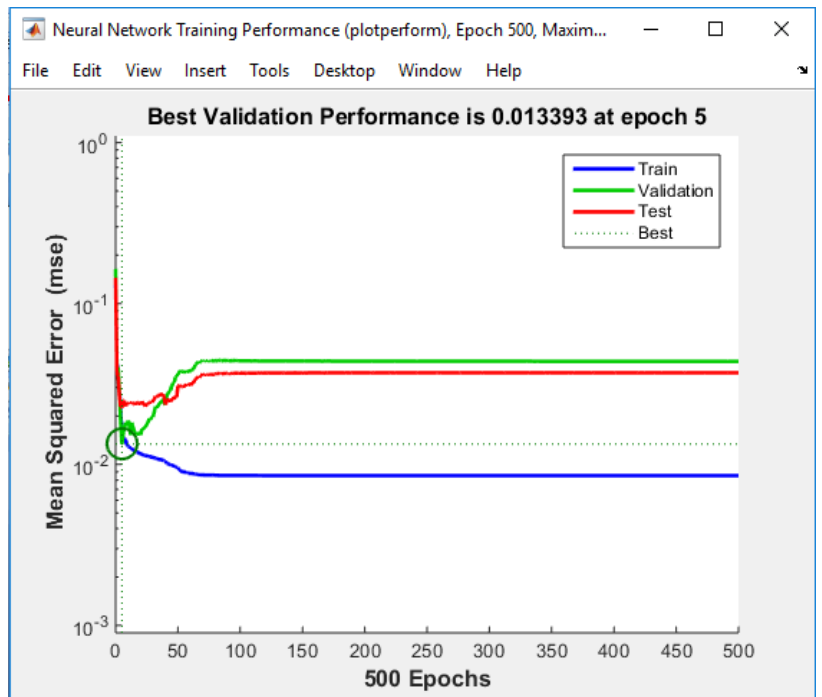

(a)

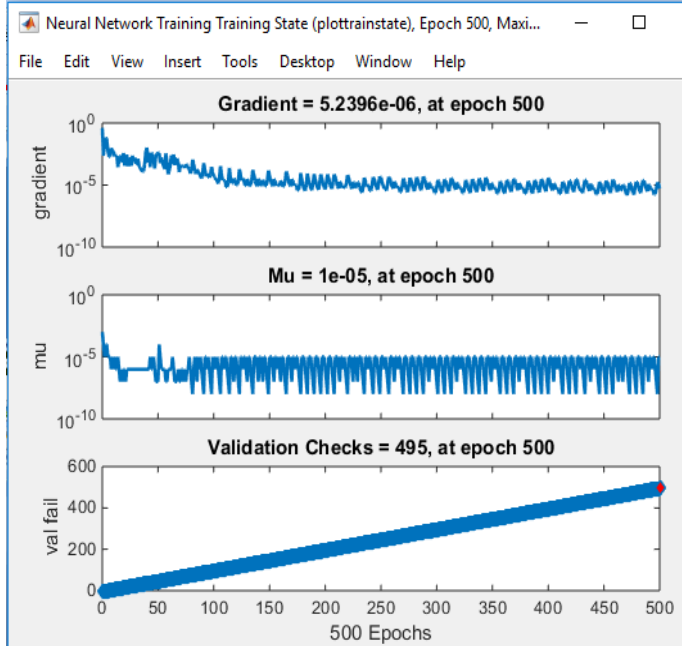

(b)
A Neural Network Training Regression (plotregression), Epoch
File Edit View Insert Tools Desktop Window HH
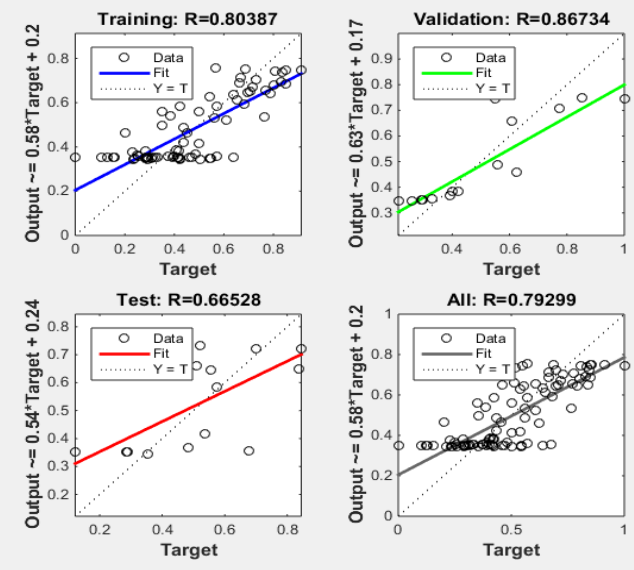

(c)

Gambar 3 (a) Hasil Plotting Mean Square Error (MSE) pada Epoch 500 (Training Pertama) (b) Hasil Plotting Training State pada Epoch 500 (Training Pertama) (c) Hasil Plotting Regression Output dan Target pada Epoch 500 (Training Pertama) 


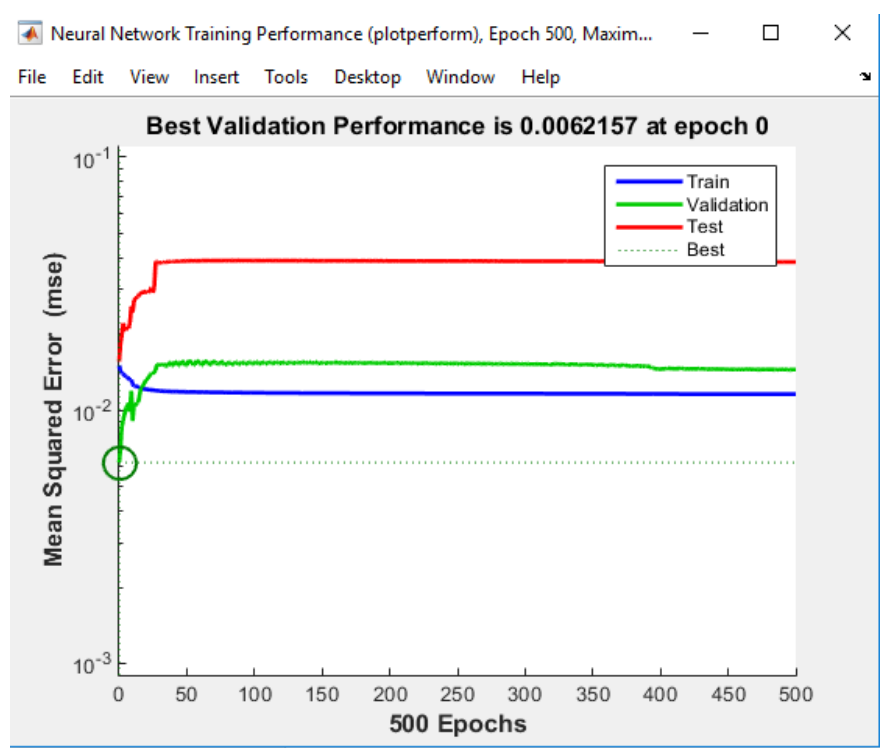

(a)

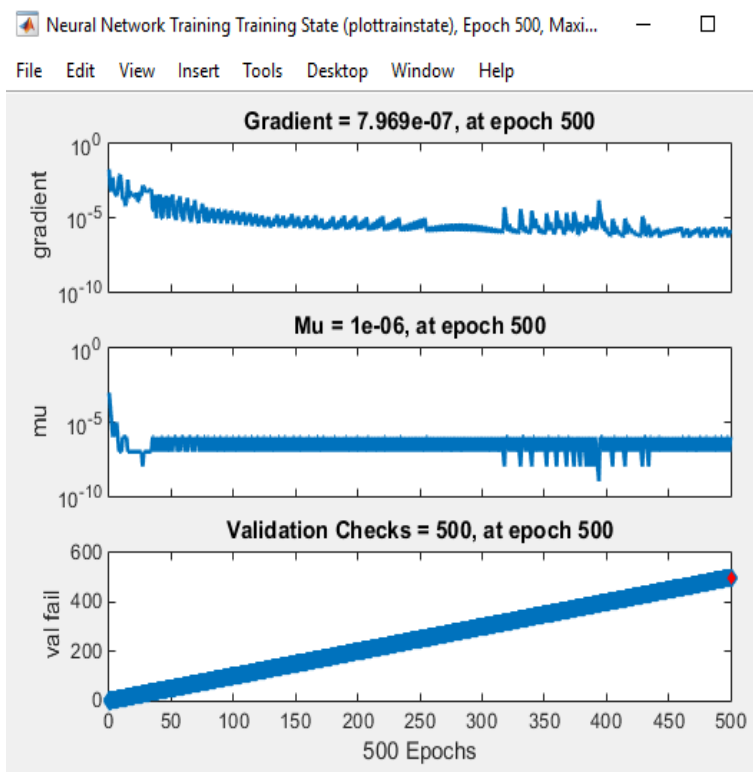

(b)

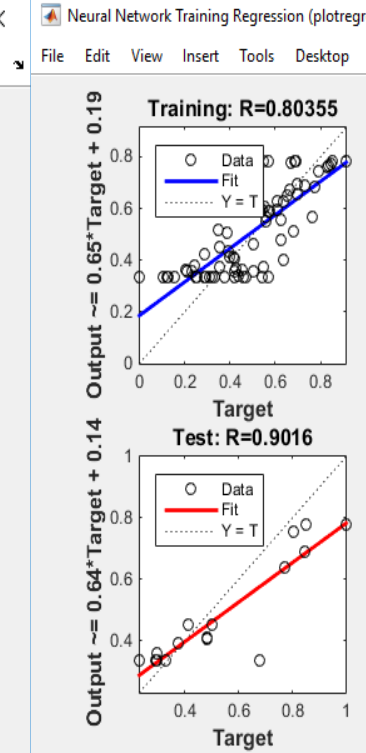

(c)

Gambar 4 (a) Hasil Plotting Mean Square Error (MSE) pada Epoch 500 (Training Optimum) (b) Hasil Plotting Training State pada Epoch 500 (Training Optimum) (c) Hasil Plotting Regression Output dan Target pada Epoch 500 (Training Optimum)

Dari tabel 4 dan 5 menghasilkan nilai kesimpulan yang berbeda tiap masing-masing pembagian data. Dimana pada tabel 4 data 5 tahun dihasilkan yang terbaik pada epoch 500, data 6 tahun pada epoch 2000, data 7 tahun pada epoch 1500, data 8 thaun pada epoch 500 dan data 9 tahun terdapat pada epoch 1000 . Sedangkan pada tabel 5 dihasilkan nilai paling baik untuk data 5 tahun pada epoch 2000, data 4 tahun pada epoch 1000 , data 3 tahun pada epoch 2000, data 2 tahun pada epoch 500 dan data 1 tahun terdapat pada epoch 500 .

Dalam studi ini disimpulkan berdasarkan Tabel 4 dan 5 bahwa dengan kalibrasi 5 tahun (2008-2012) menghasilkan nilai yang paling baik dengan Model ANN MATLAB R2014b dengan epoch 500. Hal tersebut disebabkan karena dengan digunakannya pembagian data 5-5 tahun secara seimbang atau sama untuk kalibrasi dan verifikasi dapat menghasilkan nilai yang lebih baik. Namun untuk verifikasi dan validasi dipilih data 1 tahun (2017) epoch 500 yang menghasilkan nilai yang paling baik. Dimana keduanya dipilih berdasarkan nilai NSE dengan kategori "Baik" dan Koefisien Korelasi degan kriteria "Sangat Kuat". Sehingga dipilih data 5 tahun sebagai kesimpulan Kalibrasi dan data 1 tahun sebagai kesimpulan Validasi. 
Tabel 4 Rekapitulasi Perhitungan Kesesuaian Hasil Simulasi Masing-masing Data Kalibrasi

\begin{tabular}{|c|c|c|c|c|c|c|}
\hline \multicolumn{7}{|c|}{5 tahun $(2008-2012)$} \\
\hline \multirow{2}{*}{ Epoch } & \multicolumn{2}{|c|}{ NSE } & \multirow{2}{*}{ RMSE } & \multicolumn{2}{|r|}{$\mathbf{R}$} & \multirow{2}{*}{ KR\% } \\
\hline & Nilai & Interpretasi & & Nilai & Interpretasi & \\
\hline 500 & $\mathbf{0 , 7 8 0}$ & Baik & $\mathbf{8 , 8 8 8}$ & $\mathbf{0 , 8 8 3}$ & Sangat Kuat & 18,662 \\
\hline 1000 & 0,621 & Memenuhi & 11,656 & 0,798 & Kuat & 25,255 \\
\hline 1500 & 0,667 & Memenuhi & 10,920 & 0,823 & Sangat Kuat & 25,008 \\
\hline 2000 & 0,669 & Memenuhi & 0,837 & 0,837 & Sangat Kuat & 26,328 \\
\hline \multicolumn{7}{|c|}{6 tahun $(2008-2013)$} \\
\hline \multirow{2}{*}{ Epoch } & \multicolumn{2}{|c|}{ NSE } & \multirow{2}{*}{ RMSE } & \multicolumn{2}{|r|}{$\mathbf{R}$} & \multirow{2}{*}{ KR\% } \\
\hline & Nilai & Interpretasi & & Nilai & Interpretasi & \\
\hline 500 & 0,709 & Memenuhi & 9,599 & 0,844 & Sangat Kuat & 18,193 \\
\hline 1000 & 0,692 & Memenuhi & 9,868 & 0,850 & Sangat Kuat & 19,152 \\
\hline 1500 & 0,658 & Memenuhi & 10,405 & 0,812 & Sangat Kuat & 21,861 \\
\hline 2000 & 0,726 & Memenuhi & 9,382 & $\mathbf{0 , 8 3 6}$ & Sangat Kuat & 20,032 \\
\hline \multicolumn{7}{|c|}{7 tahun $(2008-2014)$} \\
\hline \multirow{2}{*}{ Epoch } & \multicolumn{2}{|c|}{ NSE } & \multirow{2}{*}{ RMSE } & \multicolumn{2}{|r|}{$\mathbf{R}$} & \multirow{2}{*}{ KR\% } \\
\hline & Nilai & Interpretasi & & Nilai & Interpretasi & \\
\hline 500 & 0,721 & Memenuhi & 9,530 & 0,855 & Sangat Kuat & 35,037 \\
\hline 1000 & 0,583 & Memenuhi & 11,652 & 0,790 & Kuat & 41,512 \\
\hline 1500 & 0,732 & Memenuhi & 9,342 & 0,856 & Sangat Kuat & 28,718 \\
\hline 2000 & 0,665 & Memenuhi & 10,441 & 0,818 & Sangat Kuat & 34,575 \\
\hline \multicolumn{7}{|c|}{8 tahun $(2008-2015)$} \\
\hline \multirow{2}{*}{ Epoch } & \multicolumn{2}{|c|}{ NSE } & \multirow{2}{*}{ RMSE } & \multicolumn{2}{|r|}{$\mathbf{R}$} & \multirow{2}{*}{ KR\% } \\
\hline & Nilai & Interpretasi & & Nilai & Interpretasi & \\
\hline 500 & 0,736 & Memenuhi & 9,376 & 0,859 & Sangat Kuat & 31,414 \\
\hline 1000 & 0,714 & Memenuhi & 9,760 & 0,847 & Sangat Kuat & 30,512 \\
\hline 1500 & 0,705 & Memenuhi & 9,907 & 0,844 & Sangat Kuat & 30,933 \\
\hline 2000 & 0,720 & Memenuhi & 9,656 & 0,849 & Sangat Kuat & 31,682 \\
\hline \multicolumn{7}{|c|}{9 tahun $(2008-2016)$} \\
\hline \multirow{2}{*}{ Epoch } & \multicolumn{2}{|c|}{ NSE } & \multirow{2}{*}{ RMSE } & & $\mathbf{R}$ & Y D O \\
\hline & Nilai & Interpretasi & & Nilai & Interpretasi & nK\% \\
\hline 500 & 0,682 & Memenuhi & 10,257 & 0,827 & Sangat Kuat & 34,200 \\
\hline 1000 & 0,744 & Memenuhi & 9,194 & 0,863 & Sangat Kuat & 28,089 \\
\hline 1500 & 0,708 & Memenuhi & 9,822 & 0,844 & Sangat Kuat & 29,222 \\
\hline 2000 & 0,682 & Memenuhi & 10,260 & 0,827 & Sangat Kuat & 29,108 \\
\hline
\end{tabular}


Tabel 5 Rekapitulasi Perhitungan Kesesuaian Hasil Simulasi Masing-masing Data Verifikasi dan Validasi

\begin{tabular}{|c|c|c|c|c|c|c|}
\hline \multicolumn{7}{|c|}{5 tahun (2013-2017) } \\
\hline \multirow{2}{*}{ Epoch } & \multicolumn{2}{|r|}{ NSE } & \multirow{2}{*}{ RMSE } & \multicolumn{2}{|r|}{$\mathbf{R}$} & \multirow{2}{*}{ KR\% } \\
\hline & Nilai & Interpretasi & & Nilai & Interpretasi & \\
\hline 500 & 0,400 & Memenuhi & 13,096 & 0,690 & Kuat & 47,552 \\
\hline 1000 & 0,480 & Memenuhi & 12,191 & 0,745 & Kuat & 50,588 \\
\hline 1500 & 0,501 & Memenuhi & 11,951 & 0,713 & Kuat & 50,859 \\
\hline 2000 & $\mathbf{0 , 5 0 3}$ & Memenuhi & 11,919 & $\mathbf{0 , 7 5 8}$ & Kuat & 53,371 \\
\hline \multicolumn{7}{|c|}{4 tahun $(2014-2017)$} \\
\hline \multirow{2}{*}{ Epoch } & \multicolumn{2}{|r|}{ NSE } & \multirow{2}{*}{ RMSE } & \multicolumn{2}{|r|}{$\mathbf{R}$} & \multirow{2}{*}{ KR\% } \\
\hline & Nilai & Interpretasi & & Nilai & Interpretasi & \\
\hline 500 & 0,539 & Memenuhi & 12,203 & 0,737 & Kuat & 52,911 \\
\hline 1000 & 0,636 & Memenuhi & 10,842 & $\mathbf{0 , 8 0 7}$ & Sangat Kuat & 48,980 \\
\hline 1500 & 0,624 & Memenuhi & 11,024 & 0,804 & Sangat Kuat & 54,631 \\
\hline 2000 & 0,421 & Memenuhi & 13,677 & 0,653 & Kuat & 57,378 \\
\hline \multicolumn{7}{|c|}{3 tahun $(2015-2017)$} \\
\hline \multirow{2}{*}{ Epoch } & \multicolumn{2}{|r|}{ NSE } & \multirow{2}{*}{ RMSE } & \multicolumn{2}{|r|}{$\mathbf{R}$} & \multirow{2}{*}{ KR\% } \\
\hline & Nilai & Interpretasi & & Nilai & Interpretasi & \\
\hline 500 & 0,564 & Memenuhi & 11,832 & 0,761 & Kuat & 30,465 \\
\hline 1000 & 0,612 & Memenuhi & 11,157 & 0,831 & Sangat Kuat & 30,741 \\
\hline 1500 & 0,531 & Memenuhi & 12,272 & 0,748 & Kuat & 25,047 \\
\hline 2000 & 0,664 & Memenuhi & $\mathbf{1 0 , 3 8 5}$ & $\mathbf{0 , 8 2 5}$ & Sangat Kuat & 25,747 \\
\hline \multicolumn{7}{|c|}{2 tahun $(2016-2017)$} \\
\hline \multirow{2}{*}{ Epoch } & \multicolumn{2}{|r|}{ NSE } & \multirow{2}{*}{ RMSE } & \multicolumn{2}{|r|}{$\mathbf{R}$} & \multirow{2}{*}{ KR\% } \\
\hline & Nilai & Interpretasi & & Nilai & Interpretasi & \\
\hline 500 & 0,689 & Memenuhi & 9,484 & 0,831 & Sangat Kuat & 18,182 \\
\hline 1000 & 0,633 & Memenuhi & 10,311 & 0,799 & Kuat & 21,371 \\
\hline 1500 & 0,580 & Memenuhi & 11,031 & 0,774 & Kuat & 20,467 \\
\hline 2000 & 0,622 & Memenuhi & 10,456 & 0,811 & Sangat Kuat & 20,292 \\
\hline \multicolumn{7}{|c|}{1 tahun $(2017)$} \\
\hline \multirow{2}{*}{ Epoch } & \multicolumn{2}{|r|}{ NSE } & \multirow{2}{*}{ RMSE } & & $\mathbf{R}$ & \\
\hline & Nilai & Interpretasi & & Nilai & Interpretasi & KR\% \\
\hline 500 & 0,819 & Baik & 6,871 & 0,920 & Sangat Kuat & 12,268 \\
\hline 1000 & 0,706 & Memenuhi & 8,763 & 0,858 & Sangat Kuat & 15,699 \\
\hline 1500 & 0,743 & Memenuhi & 8,193 & 0,886 & Sangat Kuat & 16,535 \\
\hline 2000 & 0,696 & Memenuhi & 8,908 & 0,883 & Sangat Kuat & 17,963 \\
\hline
\end{tabular}

\section{KESIMPULAN}

Hasil kalibrasi data debit AWLR menggunakan Model Artificial Neural Network (ANN) metode "Backpropagation" periode bulanan diperoleh data yang paling baik terdapat pada data 5 tahun (2008-2012) dengan epoch 500 dengan nilai metode NSE sebesar 0,780 dan Koefisien Korelasi (R) sebesar 0,883 dari semua rentang data.

Hasil verifikasi berdasarkan metode koefisien korelasi (R) mempunyai hubungan yang relatif baik dengan kriteria $\mathrm{R}$ berada pada range 0,4 sampai 1 antara debit pengamatan dan debit model untuk semua rentang data.

Hasil uji validasi data debit AWLR pengamatan dan model periode bulanan menghasilkan nilai NSE sebesar 0,819 dengan kategori "Baik" dan Koefisien Korelasi (R) sebesar 0,920 menunjukkan kategori "Sangat Kuat" yang paling baik berada pada data 1 tahun dengan epoch 500 . 


\section{DAFTAR PUSTAKA}

Dharma, Sila., Putera, Andyana., Ardana, Putu D H. (2011). Artificial Neural Network Untuk Pemodelan Curah Hujan-Limpasan Pada Daerah Aliran Sungai (DAS) Di Pulau Bali. Jurnal Bumi Lestari. Vol 11 (I). 9-22.

Harto, Sri. (1990). Analisis Hidrologi. Yogyakarta: Universitas Gadjah Mada.

Indarto. (2012). Hidrologi Dasar Teori dan Contoh Aplikasi Model Hidrologi. Jakarta: PT Bumi Aksara.

Kusumadewi, Sri. (2003). Artifical Intelligence (Teknik dan Aplikasinya). Yogyakarta: PT Graha Ilmu

Motovilov, Y.G., Gottschalk, L., Engeland, K. \& Rodhe, A. (1999). Validation of a Distributed Hydrological Modelling Against Spatial Observations. Elseiver Agricultural and Forest Meteorology. 98 : 257 277

Sakinah, Rahimatus; Sulistiyono, Heri; Budianto, M. Bagus. (2015). Aplikasi Metode MOCK, NRECA, Artificial Neural Network, Dan Regresi Dalam Pengalihragaman Hujan-Limpasan Terkait Dengan Pembangkitan data Debit Di AWLR Matua. Jurnal Mahasiswa Jurusan Teknik Sipil. 1-12
Siang, J. (2005). Jaringan Syaraf Tiruan dan Pemrogramannya menggunakan Matlab. Yogyakarta: Andi.

Soemarto, CD. (1999). Hidrologi Teknik. Edisi 2. Jakarta: Erlangga.

Soewarno. (1995). Hidrologi Aplikasi Metode Statistik untuk Analisa Data Jilid 2. Bandung: NOVA.

Sugiyono. (2007). Statistika Untuk Penelitian. Bandung: CV. ALFABETA

Suhardi; Sulaksono, Heri Budi; Halik, Gusfan. (2017). Aplikasi jaringan Syaraf Tiruan (JST) Untuk Analisa Debit DAS Bedadung Di Kabupaten Jember. Jurnal Konferensi Nasional Teknik Sipil dan Infrastruktur, Vol I, 35-43.

Triatmodjo, B. (2006). Hidrologi Terapan. Yogyakarta: Beta Offset.

Widyastuti, Siska; Suhartanto, Ery; Dermawan, Very. (2016). Analisa Hujan-Limpasan Menggunakan Model Artifical Neural Network (ANN) Di Sub DAS Lesti. Skripsi. Tidak dipublikasikan. Malang: Universitas Brawijaya.

Yatmadi, Denny; Prihutomo, Nuzul B. (2014). Perbandingan Model Curah Hujan Limpasan antara Metode Jaringan Syaraf Tiruan dengan Metode Sacramento. Jurnal Politeknologi, Vol 13 (1), 41-42. 